\title{
Problems of Chinese Environmental Criminal Law and Its Developing Trend
}

\author{
Cong Ma \\ Law School \\ Zhejiang University of Finance \& Economics \\ Hangzhou Zhejiang Province 310018 P. R. China \\ dr.macong@gmail.com
}

\begin{abstract}
There are some existing problems of Chinese environmental criminal law in the fields of legislative idea, justification, accuracy of specific crime and efficacy of deterrent effect of punishment, and the key reason that leads to these problems is the old-fashioned legislative idea and purpose. Lawmaker in China ought to accept the doctrine of Ecocentrism, rediscover the social significance and functions of criminal law, rethink the thought of Last Resort, and adopt the idea of criminal protection in advance and priority for prevention. According to these ideas, enlarging the criminalization scope, improving the accuracy and specification of environmental Crimes and increasing the amount of punishment will become the main developing trend of Chinese environmental criminal law.
\end{abstract}

Keywords-problems; legislative ideas; criminalization; accuracy; developing trend

\section{INTRODUCTION}

Ecological environment is the material foundation of human being's survival and development. In the context of reflections on environmental disasters that were brought about by industrialization, most countries in the world begin to manage environment by legal methods. At the present times, criminal law has been playing a more and more important role in this process. In order to make criminal law work more effectively in protecting environment, environmental crimes have been stipulated in Chinese Criminal Law Code (1997), however, the legislative ideas and specific provisions of environmental criminal law are unscientific and the types and harmfulness of crimes on damaging environment are enlarging due to the so fast process of industrialization and urbanization in China, the Chinese environmental problems are becoming more serious still further now, all of which calls for effective management by criminal law. In view of this, the article firstly summarizes the existing problems of environmental criminal law, then analyses the causes of these problems and the paths of reforming, and finally gives some directional thoughts of trends of environmental criminal law in China.

\section{The EXISTING Problems OF CHINESE ENVIRONMENTAL CRIMINAL LAW}

In general, subjected to the social institution and the legislative idea, the Chinese environmental criminal law still has kinds of serious problems, which makes the criminal law ineffective in the process of governing environment by legal measures.

\section{A. Old-fashioned Legislative Idea of Chinese Environmental Criminal Law}

The legislative idea of Chinese environmental criminal law has lagged behind so much. Generally speaking, the legislative idea of environmental criminal law includes two types, which are Anthropocentrism and Non-anthropocentrism. Anthropocentrism insists that all of the legal interest criminal law protects in any case must be the benefits of mankind. Therefore, the purpose that we protect the environmental and living media separated from human beings is merely to protect the human self-interests in the end. Non-anthropocentrism then is a very complicated concept system, which insists that the environment and species that belong to the ecological system are natural existence has independent values and could coexist with human, therefore, all of the existence, such as water, air, soil, animals, plants and even the peace of living are able to become the independent objects of legal protections which could parallel with human interest. Meanwhile, the human interest just can be protected effectively through protecting these natural existences, hence, these ecological interests are natural and independent objects that deserve protecting. To be fair, it is very clear that the Chinese criminal law implements Anthropocentrism to a large extent. Take the Article 338 of Chinese Criminal Law Code for example, which stipulates Crime of Major Environmental Pollution Accident. In this provision, only when the major environmental pollution accident leads to major public or private property losses or the serious consequences of any personal injury or fatality, the conduct of actor can be regarded as a crime and being sentenced. That means, if the pollution conduct of actor does not cause any of two kinds of results that mentioned above, that conduct can not be treated as a crime even though the harmfulness of the conduct is extremely serious. This kind of provision demonstrates clearly that the legislative purpose of Chinese environmental criminal law is still following a human interest-centered pattern.

\section{B. Misunderstanding the Justification of Chinese Environmental Criminal Law}

The justification of Chinese environmental criminal law has not been explained clearly until now, and then which generates a kind of result directly that the environmental criminal law 
could not perform its general preventive effect normally to a certain degree. Now in Chinese criminal law theory circles, the justification of Chinese environmental criminal law legislation is related to Authoritarianism and Theory of Social Harmfulness. Authoritarianism insists that the reason why lawmaker stipulates environmental crimes in the Criminal Law Code is just the inevitable consequence when the state using the public power and inevitable requirement when the government managing the society. The Theory of Social Harmfulness insists that the environmental criminal law could be justified just because the environmental damage behaviors harm the society seriously, and which behaviors reach the scope that criminal law ought to intervene and sanction. However, no matter which theory only discusses the justification of environmental criminal law from perspectives beyond the norm: Authoritarianism goes against the formulation of concept of rule of law and is bad for the shaping of institutions of rule of law, and the Theory of Social Harmfulness counts against the in time sanctions and managements of environmental damage behaviors by criminal law. The modern developing trend of criminal law theory reveals that the justification of environmental criminal law should be discussed in a normal perspective within criminal law system, and following this idea, it proves the theory of penal purpose could be the best path to justify the environmental criminal law. Particularly, the thought of general prevention among penal purpose theory, can not only justify environmental criminal law in general sense scientifically but also promote criminal law to protect environmental legal interests more comprehensively, more effectively and more positively.

\section{Limited Scope of Chinese Environmental Criminal Law}

The scope of Chinese environmental criminal law is relatively limited. Before 1970s, in most countries of the world, the scope of environment protected by criminal law was basically confined to the elements that have economic values and are related to the human life and health directly, such as the source of drinking water, wild animals and plants. After 1970s, the scope of environment protected by criminal law have been enlarged, now, all the environmental elements which include air, soil, all kinds of water, all kinds of biological resources, mineral reserves, and even cultural heritages are covered by environmental criminal law. Now it has become a worldwide developing trend to enlarge the scope of environment protected by criminal law. Compared with this trend, the protective scope of Chinese environmental criminal law remains in the elements such as source of drinking water, wild animals and plants and cultivated land, so it appears that the protective scope of Chinese environmental law is relatively narrow, and especially, though the grassland has been brought into the protective scope by Chinese Administrative Law, there is still no crime about damaging grassland in criminal law field, it is no doubt that this situation can be regarded as a obvious legislative omission that ought to be amended as soon as possible.

\section{Lacks of Accuracy and Definiteness in the Specific Names of Environmental Crimes}

The specific names of environmental crimes lack accuracy and definiteness, which prevents environmental criminal law from deterring criminal conducts. In Chinese environmental criminal law, the concepts of objects of specific environmental crimes are usually confined ones, for example, the word "waste" ought to be explained in a broad sense, which means the general waste and household refuse should be included in that concept; some harmful consequences prohibited by certain crimes are of rigidity, which is bad for preventing environmental crimes; some subjective elements of environmental crimes are merely limited to negligence and do not adopt intention as one of subjective state of mind, which situation is possible to lead to a inaccurate result when applying environmental criminal law.

\section{E. Short of Deterrent Effect and Efficacy of the Punitive Measures}

The punitive measures that Chinese environmental criminal law sets are short of the deterrent effect and efficacy. For example, in specific Crime of Major Environmental Pollution Accident and Crime of Illegally Felling Trees in which criminal behaviors have serious harmfulness and even threaten public health and safety, but the lawmaker unexpectedly sets 7 years and 15 years respectively as the maximum statutory penalties for the two specific crimes, it is obvious this kind of penalty could not deter similar crimes because the severity of punishment is too light. Besides, the applying scope of fine in Chinese environmental criminal law is too narrow and lacks accuracy and manipuility, therefore, the punishment of fine lacks punitive strength and deterrent effect, and which makes the individual or the company who commits an environmental crime do not care for and are not fear of the punishment of fine, then the deterrent effect of fine disappears. Furthermore, another point that must be paid attention to is lawmaker did not stipulate compensatory and restorative measures for ecological environment, which makes it is much harder for the environment to recover in the end.

To sum up, the Chinese environmental criminal law can not take the task of fighting crimes effectively and accurately now because of the existing problems in the fields of legislative idea, justification, accuracy of specific crime and efficacy and deterrent effect of punishment. This situation causes some more negative effects for Chinese environmental criminal law in further: it is unable to accomplish the purpose of comprehensive and effective protection of environmental and human legal interest; and it is unable to play an more important role in shaping a good environmental protection consciousness, habitual awareness of law abiding and loyalty of law.

\section{The AdJustment OF Legislative IDEA IN CHINESE ENVIRONMENTAL CRIMINAL LAW}

All of the problems in Chinese environmental criminal law after all stem from the old-fashioned legislative idea and purpose. In general, if lawmaker wants to solve these so many problems and makes the environmental criminal law play a more positive role in managing environment, the four kinds of new ideas and purposes ought to be formulated and emphasized: 


\section{A. Acceptance of the Doctrince of Ecocentrism}

In the environmental criminal law field, lawmaker ought to rethink Anthropocentrism and to some degree accept and implement the thought of Non-anthropocentrism, especially the doctrine of Ecocentrism. That means, the criminal protection of environment could not be limited to the field of human life and health merely, on the contrary it ought to protect the basic foundation of living such as water, air and soil, treats them as the components of human living space and protect them seriously, and so the ecological interest ought to be regarded as a kind of legal interest to interpret. Thus, the legal interest that environmental criminal law protects, is not only human benefits, but also ecological environmental interest.

\section{B. Rediscovery of the Social Significance and Functions of Criminal Law}

The lawmaker ought to rediscover the social significance and functions of criminal law, and make the criminal law play a more positive role in shaping good environmental order and protective awareness. In traditional society, criminal law was often treated as a kind of evil that the state had to accept and apply, then the state in that circumstance often emphasized the punitive and retributive function in the society, so criminal law formed a conservative and negative image. However, under the social environment with more and more risks, the image of criminal law ought to be changed thoroughly, which means criminal law should appear a very positive and active attitude and then intervene social life positively and effectively. Finally, good behavioral pattern accord with the requirement of criminal law, habitual awareness of law abiding and good environmental protection consciousness could be formed and shaped through applying criminal punishment which means a strong general preventive measure in the end. In modern society, it has been a worldwide trend that the state uses criminal law playing a role of shaping a new society and a new social order. As a developing country of rule of law, Chinese lawmaker ought to concern this trend actively and then accept it.

\section{Rethinking of the Thought of Last Resort}

lawmaker ought to rethink the thought of Last Resort in criminal law theory. The thought of last resort originated from Japanese criminal law theory, and means that the criminal law should be used less as far as possible when the state governs citizens and the whole society, so the criminal law ought to maintain a modest and restrained position in the whole social control system. It means that the criminal law ought not to intervene the social life excessively and on the contrary a wide range of social life should be regulated by other laws except criminal law such as civil law, administrative law and even customary law. However, this kind of thought of Last Resort should be reconsidered seriously and thoroughly because the concept of Last Resort is inaccurate. It is obvious that the Japanese criminal law scholars have not come to an agreement on the issue of concept and connotation of Last Resort. In the field of Last Resort, there are so many disputes and most Japanese scholars do not sure who is right and who is authoritative. Hence, it is very doubtful if lawmaker treated an academic issue that is full of controversy as the guidelines of legislation; and the thought of Last Resort could not provide a specific and accurate criterion for the regulation scope of criminal law, which means, the thought of Last Resort has not given lawmaker a definite criterion in which situations criminal law can intervene the social life, and which kind of conducts could be treated as a crime that is worth punishing by criminal law; and from the perspective of criminal policy, the thought of Last Resort is merely a policy tendency of legislation, and it does not have an absolutely significance of guideline, which means that lawmaker may not follow this theory. That is, in the process of legislation, which kind of conduct could be chose as a crime depends on the will of lawmaker, who has a right and power of evaluation and selection, now that lawmaker has a right and power to decide how to criminalize so he does not need obey the thought of Last Resort; and finally the thought of last resort does not match the direction of Chinese criminal law legislation. Over the past 20 years it has become an obvious developing trend in Chinese criminal law field that the state is enlarging the scope of criminalization unceasingly and depends more on the criminal punishment to manage social order. It is sure that the thought of Last Resort can not justify the legislative activities of criminalization in China in the context that criminalization has become a dominant trend.

\section{Adoption of Ideas of Criminal Protection In Advance and the Priority for Prevention}

Lawmaker ought to adopt the ideas of criminal protection in advance and the priority for prevention. It is admitted that the environmental crimes have a huge potential danger and once this sort of crimes cause some loss and damage, the result can not be recovered and the loss could not be redeemed. Therefore, if criminal law starts to be employed until the conduct causes actual damages, maybe it has been already too late. Because at this time, the criminal measures can not deter the lasting damage that the harmful consequence generates any more. Hence, in the field of environmental criminal law, the idea of criminal protection in advance and the priority for prevention ought to be emphasized specially. Thus, it is justifiable that in environmental criminal law field to punish certain kinds of risks and preparation behaviors, not only punish the consequences and accomplishment behaviors. Besides, the environmental crimes often occur in the economic field, and as we all know that in this field the economic interest has a huge appeal for the ones who want to possess more money, and consequently this appeal makes them tend to take more risks, and therefore it becomes a major cause of criminal conduct. However in the environmental crime field, the ecological environment is a natural existence that has no any self-awareness, so from the perspective of victim, the ecological environment could be damaged more easily by human kind, hence in order to protect the environment more effectively, the criminal law ought to reflect the principle of prevention to a much more degree when lawmaker employing criminal punishment to fight environmental crimes.

\section{The DEVEloping TREND OF CHINESE ENVIRONMENTAL CRIMINAL LAW}

In the context of changing legislative purpose and reshaping the fundamental ideas of Chinese environmental 
criminal law, enlarging the scope of criminalization and reconstruction of the elements of existing specific crimes ought to be the right developing direction in the future.

\section{A. Enlaring the Crminalisation Scope}

The criminalization scope of Chinese environmental criminal law ought to be enlarged and the varieties of specific crimes must be increased. Nowadays, the cases must be paid more attention to is related to the behaviors of damaging grassland, wetland, natural protection area, behaviors of torture of animals and that of resistance of environmental administrative supervision and regulation activities, which harmful behaviors ought to be criminalized in the future.

\section{B. Improvent of the Accuracy and Specification of Environmental Crimes}

The accuracy of specific environmental crimes ought to be improved and the specification of environmental crimes ought to be completed.

Specifically, the Crime of Major Environmental Pollution Accident could be divided into other four crimes: Crime of Soil Pollution, Crime of Water Pollution, Crime of Ocean Pollution and Crime of Atmospheric pollution. Meanwhile, the ordinary waste including household refuse could be included the scope of these crimes; the subjective element of these crimes should be defined as not only including negligence but also intention; and the serious consequence that the Crime of Major Environmental Pollution Accident requires could be changed to risk of occurring the result in order to bring forward the protective scope.

The crimes of damaging plant resources, for example, the object of Crime of Illegally Felling Trees just covers the forest but lacks protection of undergrowth vegetation, hence the objects of this kind of crimes ought to be enlarged to undergrowth vegetation, which means the objects of these crimes include forest, shrub and vine. The objects of Crime of Smuggling of Rare Plants or Rare Plant Products ought to be changed to national key protected plants and plants products. The crime of Illegal Logging or Damaging National Key Protected Plants ought to be revised as crime of damaging wild plants.

As to the Crime of Smuggling Precious Animals or Animals Products, the scope of protection ought to be enlarged to the precious or endangered wild animals and wild animals products, and the protective scope of Crime of Illegally Hunting or Killing Precious or Endangered Wild Animals ought to be included other kinds of wild animals.

The protective scope of Crime Illegally Using of Farmland should be enlarged to other types of land such as barren mountain, intertidal zone and ravine.

In the process of specification of the environmental crimes, the accuracy of design of conduct elements ought to be emphasized particularly. For example, the types of conducts in Crime of Illegal Disposal of Solid Waste should include not only the illegally pouring out, piling up and disposing solid waste, but also the illegally purchasing, transporting and selling foreign solid waste which has certain kinds of connections with the former conducts. In the Crime of Illegally Felling Trees, the types of conducts should include not illegally felling trees, but setting fire to the woods and intentionally spreading diseases and insect pests. In the Crime of Illegally Using of Farmland, the conducts should include not illegally using farmland, but abusing and damaging the quality of soil, unreasonable reclaiming, dredging, mining soil, damaging vegetations even though using legally, which could lead to loss of water and soil, or lead to soil wind erosion, desertification, or lead to water logging, water erosion, salinization of soil, all of those conducts would make the local people lose the material resources that they rely on and influence normal production or living of local people seriously. Besides, in the process of designing the elements of specific crimes, the harmful conduct not the harmful consequence should be emphasized, and in the types of crimes of damaging plants, the judgment if the actor convicts this kind of crimes should not only be according to the quantity and proportion of the plants, but the ecological values which are firstly assessed when the harmful conducts happen. And in the process of judging environmental crimes the principle of Presumption of Causality ought to be adopted, and for example the theory of Epidemiological Causality in western countries and Strict Liability principle should be introduced in order to fight and prevent the environmental crimes

\section{Increasing the Amount of Punishment in Environmental Crimes}

The punitive measurement of environmental crimes ought to be adjusted and their statutory sentences should be increased.

\section{1) Enlarging the application scope of fine and increase its} amount.

In the environmental crimes field, because most harmful conducts are related to economic interests, the criminal law should sanction the economic interests of behaviors whom care for mostly. Therefore, it is a main developing trend about the adjustment of environmental crimes' sanctions that enlarging the application scope of fine and increasing its amount. For example, the negligence environmental crimes ought to be distributed fine in order to improve the deterrent effect of this sanction; meanwhile, some minor environmental crimes could be distributed fine only and on the contrary some serious crimes could be distributed both fine and imprisonment

2) Distribution of punishment of qualifications in environmental criminal law

Lawmaker should consider distribution of punishment of qualifications in environmental criminal law. According to the current situation in China, lawmaker could increase some kinds of penalties of depriving certain qualifications of pursuing occupations or business rights in order to incapacitate behaviors' potential ability to commit such crimes. For example, in Crime of Destructive Mining, the mining right can be deprived as a kind of penal method; then for the companies which pollute the environment, the business qualification could be deprived of.

\section{3) Increasing punitive and restorative measures}


Lawmaker ought to increase punitive and restorative measures besides criminal punishment. That means when judging the offender, the court could order the offender to restore the environment that he destroys with a certain period which measure can not only increase the preventive effect of penalty but can also save social resources and relieve national burden.

4) Increasing the amount of punishment in environmental criminal law field

Lawmaker ought to add the amount of punishment in environmental criminal law field so that the deterrent effect could be increased. For example, in the divided offenses from Crime of Major Environmental Pollution and in Crime of Illegally Felling Trees the amount of punishment ought to be increased. If lawmaker stipulates a heavier amount of punishment, which can not be regarded as doctrine of severepunishment, because the criminal legislation that is enacted through a democratic manner is absolutely the will of all the citizens in the country, which could make the legislation have the total justification.

\section{REFERENCES}

[1] P. H. Robinson, Distributive Principles of Criminal Law: Who Should be Punished How Much. London: Oxford, 2008, pp.1-5.

[2] A. Duff, Punishment. Dartmouth: Ashgate Publishing, 1993, pp. 35-46.

[3] J. Andenaes , "The Morality of Deterrence," 37 U. Chi. L. Rev. Chicago, vol. 37, pp.649-664, Summer 1970.

[4] C. Roxin, Strafrecht Allgemeiner Tell Band 1: Grundlagen Aufbau der Verbrechenslehre. München: C. H. Beck, 1997, pp.31-39. 